\section{Funding}

G.K.M. is supported by a Medical Research Council Clinician Scientist award; P.B.J. acknowledges support from the NIMR BRC for Cambridge.

\section{References}

1 Kelleher I, Keeley H, Corcoran P, Lynch F, Fitzpatrick C, Devlin N, et al. Clinicopathological significance of psychotic symptoms in non-psychotic young people: evidence from four population-based studies. Br J Psychiatry 2012; 201: 26-32.

2 Varghese D, Scott J, Welham J, Bor W, Najman J, O'Callaghan M, et al. Psychotic-like experiences in major depression and anxiety disorders: a population-based survey in young adults. Schizophr Bull 2011; 37: 389-93.

3 Woodward ND, Cowan RL, Park S, Ansari MS, Baldwin RM, Li R, et al. Correlation of individual differences in schizotypal personality traits with amphetamine-induced dopamine release in striatal and extrastriatal brain regions. Am J Psychiatry 2011; 168: 418-26.

4 Howes OD, Shotbolt P, Bloomfield M, Daalman K, Demjaha A, Diederen KM et al. Dopaminergic function in the psychosis spectrum: an [18F]-DOPA imaging study in healthy individuals with auditory hallucinations. Schizophr Bull 2012; Jan 26 (Epub ahead of print).

5 Fletcher PC, Frith CD. Perceiving is believing: a Bayesian approach to explaining the positive symptoms of schizophrenia. Nat Rev Neurosci 2009; 10: 48-58.
6 Murray GK, Corlett PR, Clark L, Pessiglione M, Blackwell AD, Honey G, et al. Substantia nigra/ventral tegmental reward prediction error disruption in psychosis. Mol Psychiatry 2008; 13: 267-76.

7 Corlett PR, Honey GD, Aitken MR, Dickinson A, Shanks DR, Absalom AR, et al. Frontal responses during learning predict vulnerability to the psychotogenic effects of ketamine: linking cognition, brain activity, and psychosis. Arch Gen Psychiatry 2006; 63: 611-21.

8 Freeman D. Delusions in the nonclinical population. Curr Psychiatry Rep 2006; 8: 191-204.

9 Johnstone EC, Russell KD, Harrison LK, Lawrie SM. The Edinburgh High Risk Study: current status and future prospects. World Psychiatry 2003; 2: 45-9.

10 Kaymaz N, Drukker M, Lieb R, Wittchen HU, Werbeloff N, Weiser M, et al. Do subthreshold psychotic experiences predict clinical outcomes in unselected non-help-seeking population-based samples? A systematic review and metaanalysis, enriched with new results. Psychol Med 2012; Jan 20: 1-15 (Epub ahead of print).

11 Berrios GE. The History of Mental Symptoms: Descriptive Psychopathology since the Nineteenth Century. Cambridge University Press, 1996.

12 Petersen $L$, Jeppesen $P$, Thorup A, Abel MB, Ohlenschlaeger J, Christensen $\mathrm{TO}$, et al. A randomised multicentre trial of integrated versus standard treatment for patients with a first episode of psychotic illness. BMJ 2005; 331: 602 .

13 Morrison AP, French P, Stewart SL, Birchwood M, Fowler D, Gumley Al, et al. Early detection and intervention evaluation for people at risk of psychosis: multisite randomised controlled trial. BMJ 2012; 344: e2233.

\title{
On Magritte's Healer
}

\section{Kate Evans}

The man does not mind being vulnerable

Does not mind letting us see

That in his heart and head live birds,

Nothing but birds and air.

He tries to look like everyone else

With his big stick, coat and hat,

But inside there is nothing but this singing

$\mathrm{He}$ is bewildered.

What can he do?

He comes and sits down in the art gallery, Attracted by the pictures of birds

And suddenly, for him, time stops.

He does not care if he ever moves again.

He has all at once become a teacher,

Has found himself, his destination

And the right surroundings for his birds.

Kate Evans' poems are from Journey into Healing, published by Survivors' Poetry in 2006 as part of Survivors' Poetry Mentoring Pamphlet Series. She was mentored by Dave Russell.

Chosen by Femi Oyebode. 